\section{Prefacio a la postdictadura}

Valderrama Castillo, Miguel. (2018). Prefacio a la postdictadura. Santiago: Palinodia. 119 pp. ISBN 978-9568438-53-1

Prefacio a la postdictadura, del historiador chileno Miguel Valderrama, se plantea como un ejercicio de lectura de la postdictadura, de "ese archivo o libro que se ha venido produciendo o escribiendo desde hace ya treinta años, desde el mismo día del triunfo del No en el plebiscito de 1988" (p. 13).

La postdictadura es el referente escogido por el autor para postular un conjunto de tesis sobre la temporalidad, la representación histórica y la imposibilidad del duelo en el contexto de la postdictadura chilena. Valderrama utiliza la figura del prefacio como advertencia o protocolo, anunciando desde un inicio el carácter aporético del ejercicio de lectura propuesto.

El archivo postdictatorial se caracterizaría por una cierta ilegibilidad, en tanto que representación de un tiempo que aparece como impensable en el marco de la crisis del régimen de historicidad moderno. En ese sentido, Prefacio a la postdictadura profundiza y amplía una reflexión sobre la historia, la posmodernidad y el tiempo presente que Miguel Valderrama ha abordado como autor en obras como Posthistoria. Historiografía y comunidad (2005), Heródoto y lo insepulto (2007), como coautor

DOI 10.5354/0719-1529.2019.53835 junto a Luis G. de Mussy en Historiografía posmoderna (2010) y como editor del volumen colectivo ¿Qué es lo contemporáneo? Actualidad, tiempo histórico, utopías del presente (2011).

En el marco de la postdictadura, lo que está en cuestión es el mismo oficio de historiador, toda vez que el conjunto de procedimientos de lectura y escritura propios de la disciplina se ven desafiados por un tiempo irrepresentable, sin temporalidad ni categorías, que pone en duda la posibilidad misma de la historia en tanto que representación mimética de la Historia.

El ámbito de reflexión del ensayo sin embargo no se reduce a una querella disciplinaria. La filosofía, la literatura, el arte y la crítica cultural son algunos de los campos interrogados en sus procedimientos y facticidades por el advenimiento de la postdictadura, porque en tanto que actos de lectura y escritura, comparten un sentido de historicidad en declive. "Si leer es descifrar, es comprender, es traducir, habría que advertir que en la tierra de duelo de la postdictadura estas operaciones de desciframiento, de comprensión, de traducción, se encuentran suspensas tras el tañido fúnebre de un fin de mundo" (p. 44).

Valderrama plantea la siguiente interrogante: “ ¿cómo nombrar el tiempo que sigue a la dictadura y en cuya sombra aún se habita bajo el nombre de postdictadura?" (p. 17), en el entendido de que el prefijo post comporta una noción de temporalidad que no se ajusta a un tiempo donde pasado, presente y futuro “se confunden y anulan en la memoria intemporal de un presente des- provisto de horizonte, de mundo, de representación" (p. 18), allí donde el tiempo presente ha devenido irrepresentable, inapropiable como consecuencia de la catástrofe.

Es el tiempo que sigue al de la dictadura el que ha devenido irrepresentable, como efecto del trauma derivado de la violencia de Estado, de la pérdida irreparable y de la desaparición. Provocando una variación en el régimen de lo sensible y la posibilidad de representación que se puede remontar a los años ochenta, por ejemplo, en el desplazamiento desde el sufijo ismo al prefijo post, en un contexto marcado por las discusiones sobre postdictadura y postmodernidad, y la problemática relación entre ambos conceptos.

Este declive de la narración histórica experimentado en el contexto de la postdictadura tendría como consecuencia la aparición de la imagen, como escena del duelo imposible, porque si la postdictadura acontece bajo la forma de un presente eterno queda descartada toda tentativa de narración o lectura.

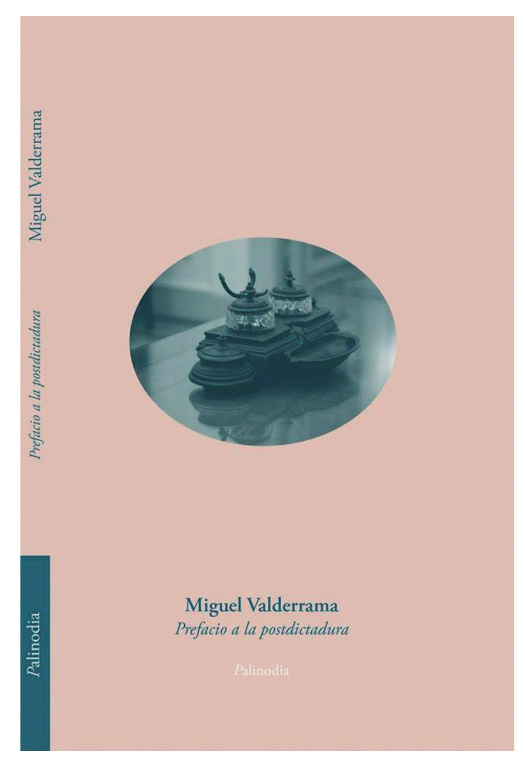


El ensayo va acompañado de una serie de fotografías del $\mathrm{Pa}$ lacio de la Moneda, que representan este advenimiento de la imagen-monumento en el ocaso de la historia, como eternización de un presente y recuerdo insistente del golpe de Estado y la catástrofe. "El golpe escenifica un trauma, una resistencia a la memoria en la memoria, una especie de herida no cicatrizable, un impedimento invencible al trabajo de transformación o figuración de la representación. $Y$ en tanto tal, es informe, no figurable en las formas de la experiencia propias del realismo, la historia y la historicidad" (p. 57).

La fotografía, como imagen, no abre paso a la catarsis ni a la dialéctica. “Es justamente la naturaleza enlutada de la fotografía la que ha hecho de ella un arte mimado en la escena de la postdictadura. Aquello que se mima en la fotografía es esa suspensión dialéctica, o mejor aún es la afirmación en la imagen de una temporalidad no dialectizable" (p. 85). En su negatividad, la imagen no se corresponde con el acto del duelo ni con la historia. De ahí que la interrupción del relato histórico dé lugar a la aparición de las imágenes. Este proceso entrega para Valderrama la clave para aproximarse críticamente a nuestro tiempo, donde un cierto pasaje a la estética otorgaría el punto privilegiado de análisis para el presente neoliberal, que asume la forma de un régimen de visibilidad.

El libro comienza con un epígrafe de Walter Benjamin: "la historia se descompone en imágenes", adelantando la tesis de Miguel Valderrama sobre la postdictadura. La tesis del Prefacio, que en tanto prefacio se juega todo en su dimensión paratextual, anticipando aquello que estamos por leer; y sobre todo, por escribir.

\section{Pablo Bivort Salinas}

Estudiante del Magíster en Comunicación Política Instituto de la Comunicación e Imagen, Universidad de Chile* pablo.bivort@ug.uchile.cl

* Con el financiamiento de CONICYT-PFCHA/MagísterNacional/2018 - Folio 22180442. 